\title{
Clash of the Titans as a Parallel Remake
}

\author{
By Antonio Sanna \\ Fall 2015 Issue of KINEMA

\begin{abstract}
REINTERPRETING MYTH AND FILM: CLASH OF THE TITANS AS A PARALLEL REMAKE
\end{abstract}

\begin{abstract}
Louis Leterrier's film Clash of the Titans (2010) is a new version of both Desmond Davis's 1981 film by the same title and the Greek myth of Perseus. Categorizing Leterrier's work is nevertheless problematic because the film partly defies many definitions of cinematic remakes elaborated by the critics in the past decades. Clash of the Titans shall be examined and evaluated in relation to both its precursor texts, with specific attention to its significantly different treatment of their narrative units.
\end{abstract}

Although remakes have been produced since the very creation of cinema at the end of the nineteenth century and proliferate nowadays (Forrester 89), critics consider them as "an underexplored subject" (Forrester and Koos 26), whose definition(s) and classification(s) are still being scrutinized and debated. Remakes are often examined in terms of their fidelity to the primary source, whether it is a literary text or the original film. As Laura Grindstaff points out, indeed, they are "a species of intertextual interpretation and translation" (275) that explicitly foregrounds "its own indebtedness to another originary text" (275). This is certainly true in the case of the film Clash of the Titans (2010), the most recent adaptation of the Greek myth of Perseus by Louis Leterrier, director of the first two Transporter films (2002-2005), Unleashed (2005), The Incredible Hulk (2008) and the recent Now You See Me (2013). The 2010 film explicitly foregrounds its indebtedness to the Greek myth and Desmond Davis's Clash of the Titans (1981), but it is likewise expressly unfaithful to both of them because of its major thematic, aesthetic and ideological changes.

Indeed, the 2010 version of Clash of the Titans is not a faithful adaptation of the Greek myth, in which the demigod Perseus seeks out Medusa's head as a marriage gift to Polydectes, king of Seriphos. The original myth narrates that, in order to accomplish this task, Perseus is firstly offered some magical objects by the nymphs, such as the winged sandals and Hades' helmet of invisibility, and is then advised by Athena on how to distinguish Medusa from the two immortal Gorgons. On his way back to Seriphos, he encounters casually princess Andromeda, who is offered as a meal to an anonymous sea monster that the demigod petrifies with Medusa's severed head. The hero finally marries Andromeda and frees his mother Danaë by turning King Polydectes and his court into stone (Apollodorus 65-68; Leeming 18 and 312). This story is altered severely in Leterrier's film. In fact, whereas the Greek myth is based mainly on the heroic actions of a single individual who is helped by or set against a series of supernatural forces, Clash 2010 is focused on the relationships between parents and children and the relationships between mortals and gods. Leterrier's film interrogates the importance of religious faith in the life of the individual by representing what happens when humans question the existence and status of the gods and when they rise up against them, as we shall see later in detail.

Secondly, the film's title reprises literally - and thus quotes/refers to/is indebted to - Davis's 1981 Clash of the Titans: the status of the film as a remake is announced through the choice of the same title of the original production. In this sense, Leterrier's film corresponds to Michael B. Drurman's description of the "direct remake" as a film explicitly based on an earlier production (qtd. in Verevis 7). However, Clash 2010 is barely faithful to the 1981 version because the structure of the original film is massively modified. On the one hand, Leterrier quotes several lines of dialogue from Davis's film, such as Queen Cassiopeia's blasphemous comparison of her own daughter's beauty with that of the gods, the three Graeae's comment "a titan against a titan" and Zeus's order "release the Kraken". The director also reproduces many details of the original film's sets, such as the small statues representing Argos' citizens around the council of the gods in Olympus. The similarities between the two films are also evident in the repetition of several narrative archetypes such as the hero's quest, his formative expulsion from the human world through the journey to the underworld, the presence of a princess in need of help and the threat coming from a series of monsters hiding in the dark. However, the most evident allusion to the 1981 film - according to Robert Stam's description 
of the term as "a verbal or visual evocation of another film" (qtd. in Verevis 20) - is achieved by means of the representation of Athena's golden owl Bubo, the hero's guide in Davis's film. Here Bubo is found by chance by Perseus (Sam Worthington) in an armoury and is immediately and most ironically set aside as a useless piece of equipment. Leterrier thus acknowledges the original film's temporal precedence, although this scene is ambiguously situated in-between the tribute and the critique, both restating and undermining the canonical authority of Clash 1981.

On the other hand, Leterrier's film is definitely distinct from the original cinematic adaptation of the myth because of the introduction of many characters that are absent in Davis's film or are presented through a different perspective. This is the case of the mysterious Djinn, desert raiders and magicians, whose name corresponds to the Arabic for "genies" but whose origin and connection with Perseus' story are never explained. More evident is the case of the character of Io (Gemma Arterton), an attractive ageless being who becomes Perseus' guide throughout the story and advises the demigod on the best course of action to be followed. Contrary to the 1981 production, in which the male play writer and poet Ammon provides the explanation and narration of historical facts and mythical details, in Clash 2010 the narrating voice of the story is assigned to a woman, who is also the repository of the story of Perseus' family (specifically, the rebellion of King Acrisius against Olympus and Zeus' punishment of him through the impregnation of his wife Danaë). Io is cursed with agelessness because she had allegedly refused a god's sexual offer and is resentful against the gods. This is supposedly the motivation behind her attempt to convince Perseus to embark on his mission by means of the suggestion that the defeat of the Kraken would offer him the occasion to strike a deathly blow at the momentarily-weakened god Hades, who has killed Perseus' adoptive and much affectionate parents near the beginning of the film. This part of the story greatly differs from Davis's film, in which Perseus (Harry Hamlin), after seeing Andromeda for the first time and instantly falling in love with her, declares: "I have found my destiny." In the 1981 cinematographic adaptation Perseus chooses to use his hybrid nature of demigod and accepts Zeus's gifts (the three weapons and Bubo) to save the princess and the afflicted city of Jaffa. It is love which motivates his heroic actions. In Leterrier's version, Perseus is instead motivated to fight against Hades by personal revenge. The absence of romantic involvement between the hero and princess Andromeda and the nearly total erasure of the sentimental at large constitutes a major deviation from the original cinematographic source.

Another great modification introduced by Leterrier regards the figure of Medusa, who has a central role in the Greek myth of Perseus. According to some versions, she is transformed into a monstrous being because she had willingly defied Athena's temple; the goddess herself therefore intervenes actively to avenge the outrage (Euripides 136, Apollodorus 67, Ovidio 191). Similarly, in the original film (whose title wrongly refers to her as a titan fighting against the other titan that is the Kraken) Perseus' arrival at her lair is postponed repeatedly by a series of scenes such as the fight against the two-headed dog, and the hero's fight against her constitutes the climax of the story. Nevertheless, Leterrier relegates Medusa to a scene that is relatively too brief and does not do justice to a character who has been often studied throughout the centuries and has been represented and interpreted in the most disparate ways. Indeed, Medusa has been seen as an allegory of an armed enemy that needs to be subjugated (Bacon 70-71), a representation of the fear of castration (Freud 415), the symbol of the social evils hidden in capitalist society (Marx 78) and the embodiment of a proto-photographic process (Owens 207), to merely name a few interpretations.

According to Io's narration, Athena, disgusted by Medusa's plea for help and comfort during Poseidon's sexual violation, transformed the beautiful woman into a monstrous creature whose hair is made of snakes, and then confined her to a temple near the entrance of the underworld. Medusa (Natalia Vodianova) can never leave her home, but must only wait for men to visit her, although they mainly have homicidal intentions against her. She has thus been unjustly punished by Athena, who also ensured that she received no human comfort, women not being allowed in her prison and men being petrified immediately by her glance. Rather than lingering on her monstrosity, the film thus focuses on this character's unjust punishment and on her solitude.

Contrary to the exclusively-monstrous and never-pitied representation of her given in Davis's film, Clash 2010 underlines the solitary condition of Medusa, an aspect that has been hitherto pointed out only by Ann Stanford in her 1977 poem "Medusa" ("I was alone. I am alone. My ways / divide me from the world, imprison me in a stare", 162). The representation of this specific aspect of the Gorgon is achieved primarily 
through the choice to depict her face as still beautiful and human [Image 1] and, secondly, is reinforced by the film's soundtrack, composed by Ramin Djawadi. Indeed, during the track titled "Medusa", the lyrical voice of a single soprano seems to reproduce both the woman's prayer for comfort while being raped by Poseidon and her present loneliness due to the imprisonment. The voice of the soprano echoes over the melody of the melancholy orchestral track precisely like Medusa's laughter and cries echo among the ruins of her subterranean home. This is further confirmed in the moment of Medusa's decapitation, which is accompanied by the part of the musical track "Eyes Down" that ends with a prolonged and piercing sound. Such a sound is very similar to a woman's high cry: the final silencing of a woman's voice and the interruption of her aggressive actions coincide with the end of the track, with a sound that leaves only an echo of what Medusa has been, her last cry against the violence and injustice she suffered. In this sense, Clash 2010 challenges the semantic fixity of Medusa's figure, adding a possible aspect of her character that has almost been ignored in previous films.

On the other hand, the ambiguity regarding Medusa's "intrinsic doubleness" (Marjorie 1) due to her beauty and monstrosity is maintained in Clash 2010. Indeed, many literary sources describe her with opposite adjective and characterize her respectively as "frightful and grisly" (Homer 94) or as "fair-cheeked" (Pindar 15). Such ambivalent descriptions are epitomized by Percy Bysshe Shelley's 1819 poem "On the Medusa of Leonardo da Vinci in the Florentine Gallery" which affirms that "Its horror and its beauty are divine" (128). In Leterrier's film, her doubleness is rendered visually by means of the fact that Medusa physically mutates before turning her preys into stone: her facial features change, her skin apparently becomes coarse and, almost in a vampiric way, her canine teeth are prolonged. The face she shows to the men who visit her prison loses the last remnants and physical traces of humanity and she becomes the ugly monster of the curse she has suffered [Image 2]. Medusa here is all the more exemplary of Barbara Creed's conception of the "monstrous feminine" (111), which represents an ominous threat to male dominion and power. Her female empowerment, expressed through her "castrating" gaze and through the phallic tail she uses to entrap some of Perseus' companions, is enacted through her refusal (and punishment) of the male gaze. This is the last face men see before becoming inert statues furnishing her home. Literally, they are not her human companions or life-long partners, but mere objects around her. We could even consider them as becoming part of the subterranean environment, following Jean-Pierre Vernant's suggestion that the petrification caused by the eyes of the Gorgon - the passage from animated to fixity - implies "the metamorphosis from the human realm to the mineral realm, and thus into what is most antithetic to human nature" (180).

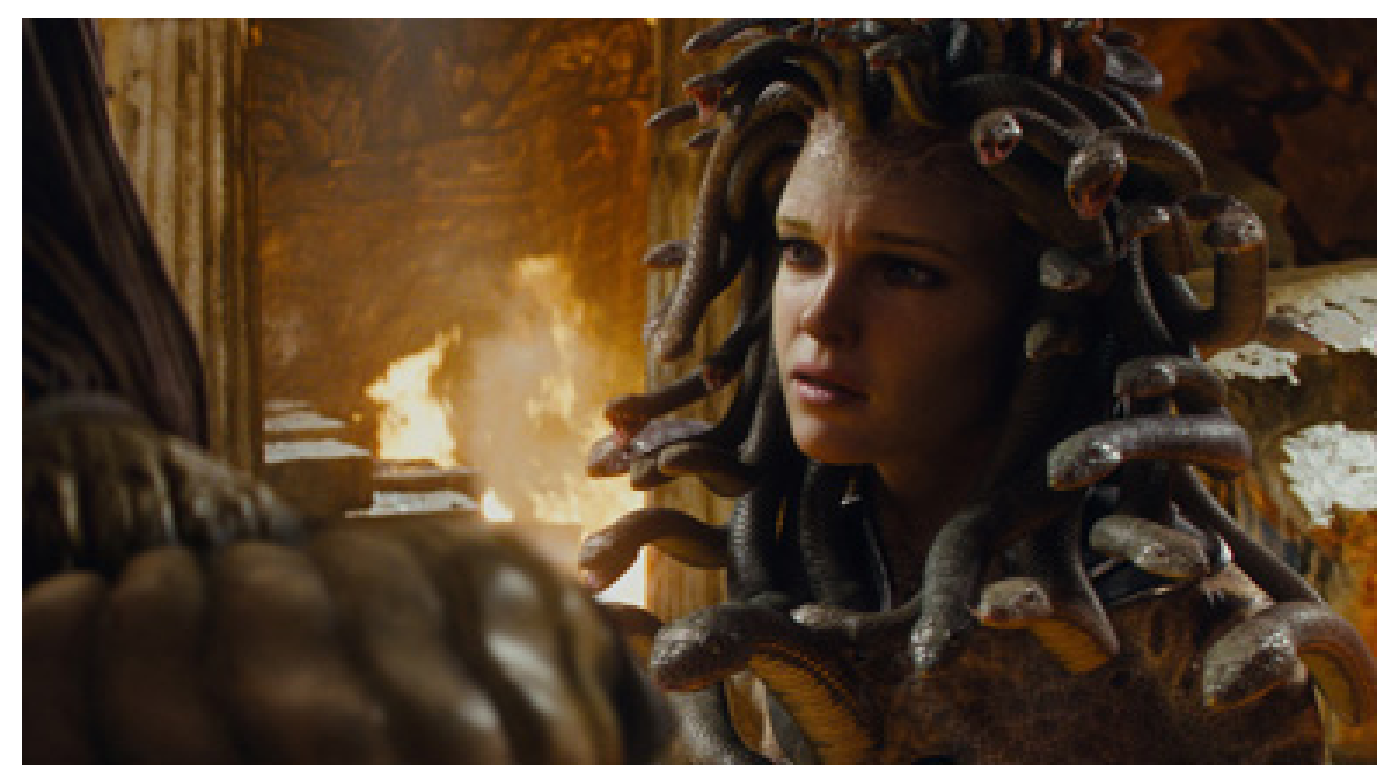

Figure 1: Medusa (Natalia Vodianova) shows mainly a human face in the 2010 version of Clash of the Titans

As the scenes hitherto examined demonstrate, Clash 2010 could be therefore considered as an "acknowledged, transformed remake", according to Harvey Roy Greenberg's definition, which recognizes a film's indebtedness 
to an original source but also its substantial transformations of it (qtd. in Verevis 9). However, Leterrier's film also seems to exemplify the triangular relationship of a work with its two sources (the literary and the cinematic) that, according to Thomas Leitch, characterizes "the true remake". In his analysis (45-50), Leitch distinguishes four types of remake: re-adaptations (which repudiate the earlier film or films and attempt to faithfully reproduce the original text); homages (which value the original film and subordinate to it their own textual claims); updates (which critically or ironically revise their literary source); and true remakes (which attempt "to annihilate the model they are honouring - to eliminate any need or desire to see the film they seek to replace" (50)). Clash 2010 cannot be defined as a re-adaptation, it being barely faithful to the original myth, as we saw before. Nor we can consider it as a homage, because it distances itself from Davis's film by introducing new characters, privileging different thematic concerns and utilizing new visual effects, as we shall see later in detail. Furthermore, the film only partly corresponds to Leitch's definition of updates as films that transform the original literary source "by transposing it to a new setting, inverting its system of values, or adopting standards of realism that implicitly criticize the original as dated, outmoded, or irrelevant" (47). Clash 2010 is not an adjustment of the primary mythical source to contemporary times because the temporal setting is Ancient Greece. Nevertheless, the film favours a different system of values, especially if we consider Perseus' vindictive motivation against Hades or the characters' irreverent attitude towards the Olympian gods.

Clash 2010 could be rather considered as an "update" of Davis's film for its use of computer-generated special effects, which cause the original film to appear definitely "dated" and "outmoded" in comparison. Leterrier has certainly taken advantage of the new technologies created in the nineteen years intervening between the two productions and the film can be rightfully seen as an improvement of the realization of the mythological story through the use of present-day special effects. In this sense, it certainly meets the expectations of the members of the audience who are very demanding about the need for the visual realism or for the visual sensationalism that is often obtained through computer-generated images. This is exemplified by the scenes that portray Acrisius (Jason Flemyng) while attempting to revenge against Zeus by killing his own stepson Perseus. Acrisius - here an ally of Hades - is not Perseus' human grandfather as in the Greek myth and he is also unnecessarily identified with the character of Calibos from Davis's film. He becomes merely the vehicle for the insertion of several fights during the story, fights which assume supernatural qualities when some enormous scorpions sprung from the blood pouring from the villain's wounds and assault violently the heroes. These scenes are carefully-choreographed and accompanied by an appropriately fast-paced soundtrack. Moreover, they are punctuated by the insertion of slow motion frames and rendered all the more realistic through both the sound effects and the accuracy of details such as the dust and earth risen by the characters and the creatures during the action. In this sense, Leterrier's work could be thought of as a technological update of the 1981 film, the fights between the hero and his adversaries being much more accurate and realistic.

Nevertheless, we cannot consider Clash 2010 as a true remake either, according to Leitch's definition, which implies the ascription of value to the literary text through the invocation of the previous adaptation as a failed attempt to completely realize the story's potential or actual value. Indeed, Leterrier's film attempts only partly to eliminate the previous adaptation but rather confronts it on several occasions. The expression of a series of modern preoccupations such as the relationship of human beings with the divine, the human need for - or refusal of - supernatural guidance and support, and the conflictual relationships between parents and children assume a greater cultural value when confronted with Davis's treatment of the same subjects. It is by confronting the two films that Leterrier's suggestion that, perhaps, contemporary people have now changed their views and beliefs on religion appears all the more evident.

Indeed, the two films can be easily juxtaposed - or set against each other - because of their opposite characterization of the gods and different depiction of the attitude of human beings towards them. In Clash 1981, the Olympian gods are benevolent and very interested in the welfare of the human community. Although sometimes portrayed as a severe leader, Zeus (Laurence Olivier) is affectionate towards his human subjects and cares for justice to be assigned, laws to be respected and morality to be upheld [Image 3]. This is exemplified by the fact that he punishes personally King Acrisius and Calibos for their crimes, assuming directly the role of jury of human affairs and executioner of the penalty. Moreover, he is rarely paternalistic towards the other gods, but rather accepts their suggestions and proposals. The other Olympian deities 


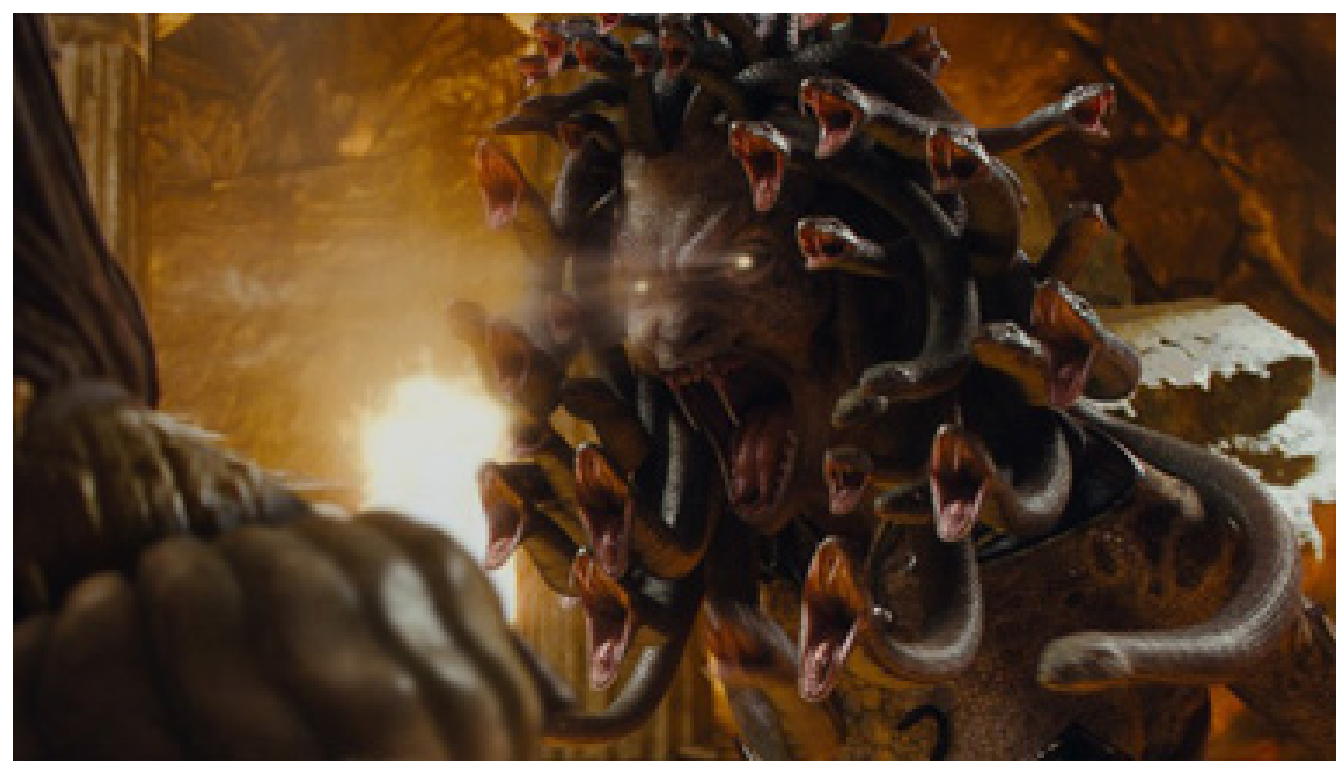

Figure 2: Image 2: Medusa transforms into a monster when petrifying her male preys

(there are only six of them in Clash 1981) are seriously interested in human (personal and love) affairs, discuss pleasantly about them and never demonstrate an inimical attitude towards mortals at large.

Leterrier's film, instead, presents the primary gods of Ancient Greece as egocentric, self-concerned and even malevolent. They are not as omnipotent and capricious as the deities of the myth, who observe from afar human vicissitudes or play disrespectfully with the mortals' (sexual) lives and feelings. Clash 2010 portrays deities as ready to move war against humanity and as even adversarial and treacherous against each other. The story begins with the narration of the defeat of the Titans and the division of the earth into the three reigns of heavens, seas and underworld, whose lordship is respectively assigned to the divine brothers Zeus, Poseidon and Hades. Contrary to the myth stating that the three gods "shook lots in a helmet for the lordship" of the different reigns (Graves 59), in Clash 2010 Zeus tricks Hades and banishes him to the dark and miserable underworld to rule over "the unhappy dead" (Leeming 167). This creates the premise for the Dark Lord of Tartarus to plan his revenge against the twelve gods living in the eternal sunshine of Olympus. Indeed, the sneaky Hades -"the gloomy one" as he is defined by the poet(s) of the Homeric Hymns (qtd. in Leeming 97) - convinces treacherously his brother Zeus to punish human beings for having stopped praying for the gods. Hades, performed excellently by Ralph Fiennes, one of the best interpreter of villains of the last decade, proposes to terrorize all humans with the fear of death in order to reconcile them back to (and strengthen again) the Olympian gods. Human prayers are in fact necessary to feed the immortality of the gods, who are here presented as weak and scared of losing their eternal life. Leterrier's deities are not as indifferent and composed as we would probably expect gods to be; they are worried about their weakness and vexed against their mortal progeny. We could even argue that they have almost fallen from their position as the supreme beings in the universe into paranoia and despair. This is particularly evident in a scene very unfortunately deleted from the final cut, but inserted among the DVD specials - which clearly shows the congregation of the twelve Olympians (only Dionysus is absent, although one seat is empty and Hestia still holds her place) while debating human infidelity in front of an all-commanding and severe Zeus, who is introduced in the very moment in which he refuses to listen to any proposal and debate on the subject [Image 4].

Human rebellion against the gods is another major thematic innovation introduced by Leterrier. In Clash 1981 the human characters are very reverent, respectful and obedient towards the deities and they never question their power or doubt their existence. For example, when the statue of Thetis breaks up during Perseus' and Andromeda's wedding and the goddess (interpreted by Maggie Smith) curses Queen Cassiopeia, all of the human characters present in the temple are extremely scared of the angered goddess and accept 


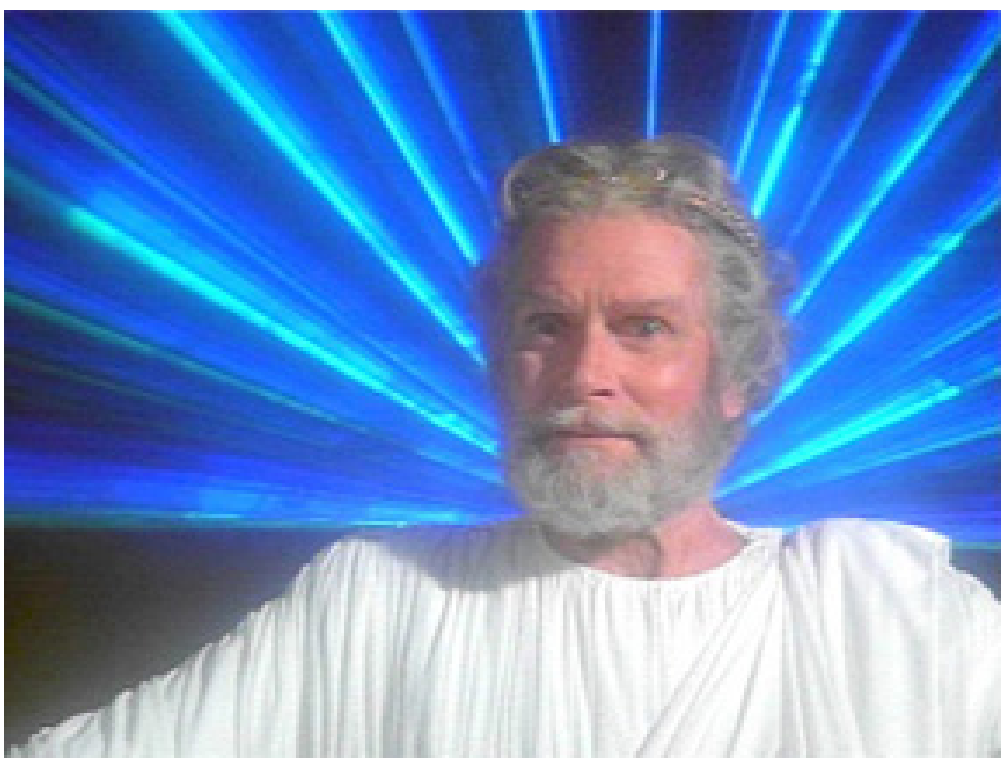

Figure 3: Image 3: A severe but benevolent Zeus (Laurence Olivier) in Davis's Clash of the Titans

silently the retribution she demands. In Clash 2010, instead, temples are burnt down, the places of worship are abandoned, idols and statues are destroyed, and blasphemous challenges are cried loudly against the gods. This is a representation of religious anarchy; it is not a glorification of scientific evidence as opposed to religious faith, but a refusal to submit to the power (and will) of the gods. In fact, although aware of the gods' actual existence, humans have declared war against them, refuse to serve any longer and think egoistically only of their own mortal lives. This perspective is partly justified by the fact that the ills of humanity such as plagues and famine are all attributed to the indifference and wickedness of the gods. Leterrier represents Argos' citizens as living in poverty, dirt and illness, as desperate and afflicted by their misery.

On the other hand, the film also implies that it is the lack of religious faith that causes the gods' anger and subsequent punishment of humanity. Indeed, although they should perhaps be thankful to the gods for living in opulence and comfort, the nobles who attend the royal palace are pictured as arrogant and with no fear of divine punishment, an issue which seems to reprise the verses of Homer's Odyssey in which Zeus complains that humans always blame the gods for the evils they themselves produce (Book I, vv. 3134). This is exemplified by the fact that during a sumptuous ceremony King Kepheus (Vincent Regan) and Queen Cassiopeia (Polly Walker) declare the beginning of the "era of man", thus becoming the promoters of religious anarchy. The queen compares blasphemously Andromeda's beauty to that of Aphrodite and does not recognize Hades when the god appears, addressing him with a disrespectful tone of voice and refusing to kneel before him.

The film then explores what becomes of human life without the aid of the gods, and attempts to answer the question: can mortals live without their deities? Apparently, the director's reply would seem to be negative, since chaos reigns in Argos after Hades, taking advantage of the situation to increase his own strength while appearing to serve Zeus's design, threatens to destroy the entire city by unleashing the monstrous Kraken in exchange for the sacrifice of princess Andromeda (Alexa Davalos). People in the streets conspire against their regents, rebel against the soldiers, and kill the King. Leterrier represents the end of the social rules and laws of the human community as consequential to the rebellion against the gods and the lack of religious faith. This is underlined particularly by the representation of the character of Prokopion (Luke Treadaway), a fanatic young man who preaches initially for the forgiveness of the Olympian gods, but then convinces Argos' populace to sacrifice the princess in order to save the city, appealing to the abolition of class differences (which is not particularly realistic for the historical context of Ancient Greece and for the Greek myth).

The balance of power of the battle between gods and mortals thus comes into the hands of Perseus, the demigod son of Zeus who is the vehicle for another theme developed consistently in Leterrier's story and 
absent in Clash 1981, that of conflictual familial relationships. Indeed, Perseus demonstrates repeatedly his disrespect for Zeus' paternal role and refuses his help. He does not accept his status as a demigod and refuses to pray, even when divine help could probably save him from approaching death. His conflict regards accepting Zeus as his real father: he often states this, especially when facing the god personally after the encounter with the Stygian witches. In this scene, Zeus is depicted as a severe parent who attempts to convince Perseus of a higher truth and offers him sanctuary on Olympus. The demigod behaves almost like an adolescent (a particular apparently confirmed by the fact that Zeus calls him "boy") who does not accept his father's guidance and advice.

On the other hand, Zeus - interpreted majestically by Liam Neeson as a regent divided between paternal love for his mortal children and anger for their insolent defiance - is torn between his sincere affection towards his offspring (both demigods and humans at large) and the severity that his role demands. In fact, during the council of the gods and the initial part of the film, he is represented as an inflexible leader whose rage is due to the loss of control over his subjects. Contrary to the Zeus interpreted by Olivier in Davis's film, who favours and protects his son Perseus as soon as he is born, grows proud of his appearance and praises his heroic actions in front of the other gods, Leterrier's Zeus is characterized by, in Hades' words, "wrath tempered with love". Indeed, although angered by Perseus' "blasphemous" refusal to acknowledge the gift of life he himself has given humanity, the Olympian paterfamilias brings to the surface also his tenderness and comprehension. A positive message is suggested in the last scene of the film when Zeus thanks his demigod son for having defeated Hades and affirms: "I wanted men to worship us again, but I didn't want it to cost me a son". He thus acknowledges his paternal affection to be stronger than his will to rule over humankind and, before saying goodbye, he adds: "Be good to them. Be better than we were". The father of the gods thus recognizes the deities' faults against human beings and elaborates on his apparent intention not to intervene in human matters any longer. This is not an abandonment or neglect of human beings or of children, but a way to put them in charge of themselves and to trust their abilities to grow and improve on their own.

Clash 2010 could therefore be considered as a very free translation of both of its sources. The film is not a retelling of Davis's adaptation of the Greek myth, but a repetition of it with major differences and variations, a recreation of the myth which also continually refers to its first cinematic adaptation. This exemplifies the dichotomous attitude of competition and revision that characterizes many remakes. Indeed, by basing the film's plot on themes that have no correspondence in the Greek myth or in Clash 1981, Leterrier seems to be re-visioning both the original stories. This affirmation is in accord with Leslie Stern's argument that "remakes are also compelled to register variation and difference (from the originals)" (qtd. in Verevis 4). However, how much can a remake differ from its source(s) before being considered as a work standing on its own terms? Is this a question of degrees or of authorial intentions? First of all, we have to recognize that, as Grindstaff underlines, "the most obvious reason to remake a film is financial" (302): a remake is produced in view of the profits it can accumulate, it is commercially grounded. On the other hand, and in order to achieve this end, the producers and director attempt and need to meet the expectations of the contemporary audience. As Leitch has evidenced, this is made of: "the audience that has never heard of the original film [the remake] is based on, the audience that has heard of the film but not seen it, the audience that has seen it but does not remember it, the audience that has seen it but liked it little enough to hope for an improvement, and the audience that has seen it and enjoyed it" (40). The film's producers and director aim potentially to win over all of these viewers.

Whether Clash 2010 is better than its original sources, or whether it adds to or diminishes them, is a different (and subjective) matter. Certainly, people who are nostalgic of the visual style of the 1980s, or of the (stopmotion) special effects of the period as well as the spectators who have grown affectionate towards the 1981 version and do not feel the need for a remake of it shall not appreciate the 2010 film. Leterrier's work could similarly delude the expectations of an audience who is familiar with the Greek myth and demands adherence to it. On the other hand, those people who are not completely content with the 1981 version shall probably appreciate Clash 2010 for its special effects or the larger cast of actors. In the same respect, Leterrier's film could appeal to the spectators who are willing to accept some changes to the original sources such as the more fast-paced story, the introduction of new characters or the fact that Perseus refuses the divine part of himself. 
Finally, it is also legitimate to assume that Clash 2010 could be appreciated or denigrated in its own terms as a self-sufficient narrative. As Constantine Verevis has pointed out, in fact, "audiences come to the new versions with varying degrees of knowledge and expectation" (145). Certainly, the knowing spectator experiences what Linda Hutcheon defines as "an interpretative doubling, a conceptual flipping back and forth between the work we know and the work we are experiencing" (139). Hutcheon refers specifically to the relationship between a cinematic adaptation and its literary source, but her argument could be similarly applied to Leterrier's work too for its triangular relationship with both of its sources. On the other hand, it is rightful to consider also all of those spectators who had no knowledge or recollection of - as well as those who willingly chose to ignore - the precursor texts and who (shall) evaluate the film without establishing any confrontation or juxtaposition with the Greek myth or with Clash 1981.

It is therefore difficult to categorize Clash 2010 according to one precise definition of remake among those offered by the various critics in the past decades. As I have demonstrated, none of these definitions produces a comprehensive description of Leterrier's film. My suggestion would be to interpret this film as a revision of both of its sources, a reinterpretation of them. We cannot exclude the director's intention to lead the spectators and critics back to source both of its precursor texts, considering the many references to them and the choice to name the film after Davis's title. Nevertheless, Clash 2010 absorbs and alters its sources simultaneously, replicating them but with vigorous mutations. Furthermore, we have to recognize that there is a certain competition between the two films (it being perhaps now created only in our minds), but the new version does not necessarily supersede the old one. Rather, I would suggest that it offers a valid alternative to it and could therefore be seen as a companion to Davis's version. Leterrier's work could be considered as a sort of "parallel re-make", by which phrase we could intend a form of reconstruction and remodelling of the original sources which is characterized by the expressed intention to quote them and realize their full potentialities, but is also dictated by the need to distance itself from them.

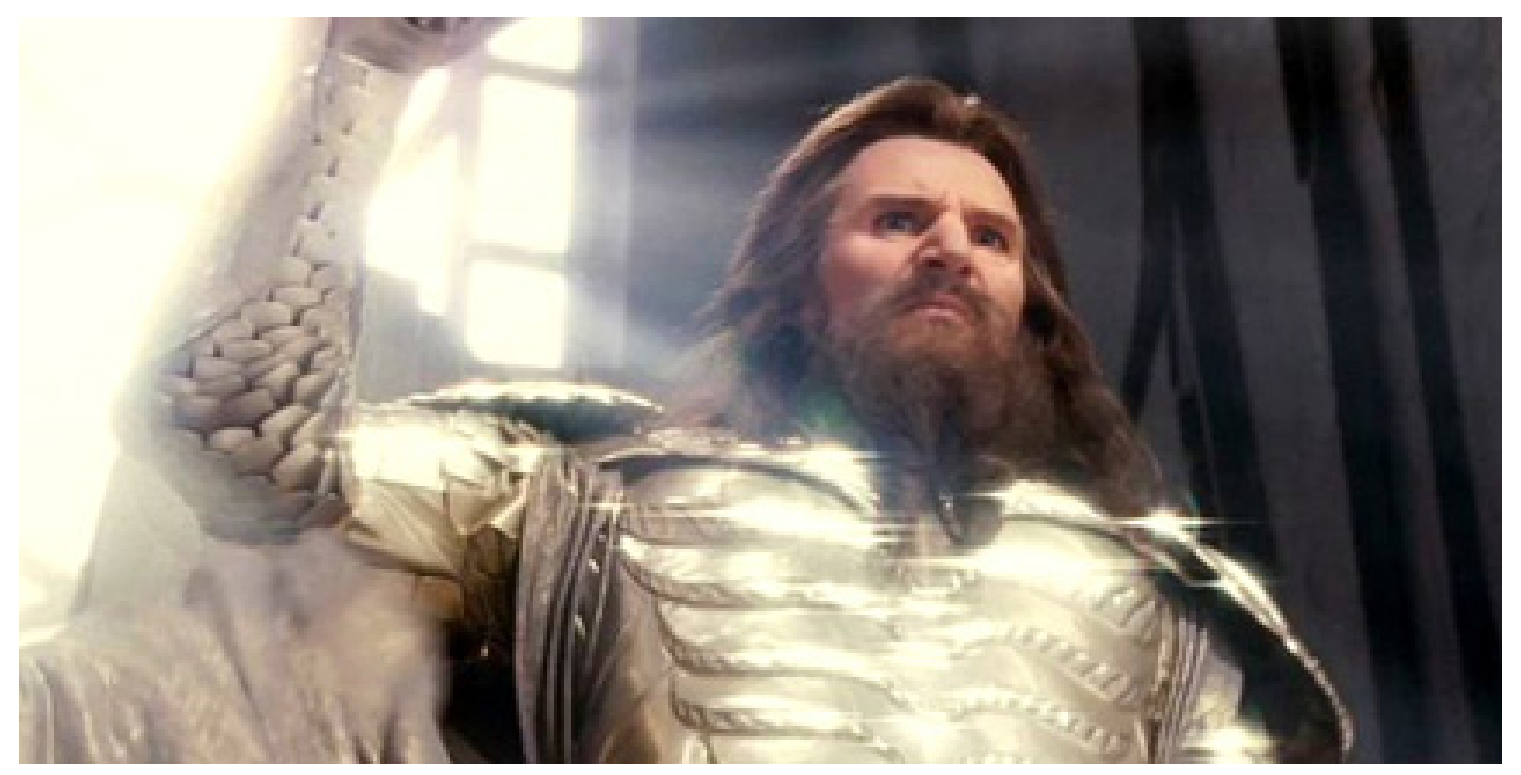

Figure 4: Image 4: Liam Neeson interprets a resentful and belligerent Zeus in Leterrier's film

\section{References}

\section{Works Cited}

Apollodorus. The Library of Greek Mythology. Trans. Robin Hard. Oxford: Oxford University Press, 2008.

Bacon, Francis, "Tyranny and the Art of War." The Medusa Reader. Eds. Marjorie Garber and Nancy J. Vickers. Trans. James Spedding. New York: Routledge, 2003. 69-71. 
Creed, Barbara. The Monstrous Feminine: Film, Feminism, Psychoanalysis. London: Routledge, 1993.

Euripide, Jone. Trans. Ettore Barelli. Milano, IT: Rizzoli, 1959.

Forrester, Jennifer. "The 'Personal' Touch: The Original, the Remake, and the Dupe in Early Cinema." Dead Ringers: The Remake in Theory and Practice. Eds. Jennifer Forrester and Leonard R. Koos. Albany, NY: State University of New York Press, 2002. 89-126.

Forrester, Jennifer and Leonard R. Koos (eds.). "Reviewing Remakes: An Introduction." Dead Ringers: The Remake in Theory and Practice. Albany, NY: State University of New York Press, 2002. 1-36.

Freud, Sigmund. "La Testa di Medusa." Opere 1917-1923. Ed. Cesare Luigi Musatti. Trans. Silvano Daniele. Torino, IT: Boringhieri, 1977. 415-16.

Garber, Marjorie and Nancy J. Vickers (eds.). Introduction. The Medusa Reader. New York: Routledge, 2003. 1-7.

Graves, Robert. The Greek Myths: The Complete and Definitive Edition. London: Penguin Books, 2011.

Grindstaff, Laura. "Pretty Woman with a Gun: La femme Nikita and the Textual Politics of 'The Remake'." Dead Ringers: The Remake in Theory and Practice. Eds. Jennifer Forrester and Leonard R. Koos. Albany, NY: State University of New York Press, 2002. 273-308.

Homer, The Iliad. Trans. F.W. Newman. London: Walton and Maberly, 1856.

, Odyssea. Trans. Enzio Cetrangolo. Milano, IT: Fabbri, 2000.

Hutcheon, Linda. A Theory of Adaptation. New York: Routledge, 2006.

Leeming, David. The Oxford Companion to World Mythology. Oxford: Oxford University Press, 2009.

Leitch, Thomas. "Twice-Told Tales: Disavowal and the Rhetoric of the Remake." Dead Ringers: The Remake in Theory and Practice. Eds. Jennifer Forrester and Leonard R. Koos. Albany, NY: State University of New York Press, 2002. 37-62.

Marx Karl, "The Medusa of Capitalist Production." The Medusa Reader. Eds. Marjorie Garber and Nancy J. Vickers. Trans. Samuel Moore and Edward Aveling. New York: Routledge, 2003. 77-78.

Ovidio, Opere: 2. Le Metamorfosi. Trans. Guido Paduano. Torino, IT: Einaudi, 2000.

Owens, Craig. "Barbara Kruger and the Medusa Effect." The Medusa Reader. Eds. Marjorie Garber and Nancy J. Vickers. New York: Routledge, 2003. 203-09.

Pindar, "Medusa and Music." The Medusa Reader. Eds. Marjorie Garber and Nancy J. Vickers. Trans. Geoffrey S. Conway. New York: Routledge, 2003. 14-15.

Shelley, Percy Bysshe. "On the Medusa of Leonardo da Vinci in the Florentine Gallery." Poesie. Ed. Roberto Sanesi. Milano, IT: Mondadori, 1983. 128-30.

Stanford, Ann. "Medusa." The Medusa Reader. Eds. Marjorie Garber and Nancy J. Vickers. New York: Routledge, 2003. 161-62.

Vernant, Jean-Pierre. The Universe, the Gods, and Mortals. Trans. Linda Asher. London: Profile Books, 2002 .

Verevis, Constantine. Film Remakes. Edinburgh: Edinburgh University Press, 2006.

Vickers, Nancy J. "The Face of Medusa." The Medusa Reader. Eds. Marjorie Garber and Nancy J. Vickers. New York: Routledge, 2003. 232-237.

\section{Filmography}

Clash of the Titans. Dir. Desmond Davis. Metro-Goldwyn-Mayer, 1981. 
Clash of the Titans. Dir. Louis Leterrier. Warner Bros, 2010.

\section{Reports}

Photo credits: Clash of the Titans (2010): Warner Bros 2010.

\section{Author Information}

Antonio SANNA received his $\mathrm{PhD}$ at the University of Westminster in London. His publications include articles on James's "The Turn of the Screw", Stoker's Dracula, H. G. Wells's The Island of Dr. Moreau, Victorian ghost stories and Beowulf; the Alien quadrilogy, Ridley Scott's Hannibal and the Harry Potter films. He has contributed to The Dictionary of Literary Characters. 